\title{
THE EFFECTS OF 1-METHYLNAPHTHALENE AFTER INHALATION EXPOSURE ON THE SERUM CORTICOSTERONE LEVELS IN RATS
}

\author{
RADOSŁAW ŚWIERCZ and MACIEJ STĘPNIK \\ Nofer Institute of Occupational Medicine, Łódź, Poland \\ Department of Toxicology and Carcinogenesis
}

\begin{abstract}
Objectives: This paper reports on the trend of the stressogenic stimulus caused by a repeated exposure to 1-methylnaphthalene (1-MN) vapors at the nominal concentrations of $0 \mathrm{mg} / \mathrm{m}^{3}$ (the control restrainer), $50 \mathrm{mg} / \mathrm{m}^{3}$ or $200 \mathrm{mg} / \mathrm{m}^{3}$ in the nose-only inhalation system, by analyzing the serum corticosterone (CORT) levels in rats. Material and Methods: Three groups of rats were exposed in restrainers to 1-MN vapors at the nominal concentrations of $0 \mathrm{mg} / \mathrm{m}^{3}, 50 \mathrm{mg} / \mathrm{m}^{3}$ or $200 \mathrm{mg} / \mathrm{m}^{3}$ for 5 days. One control group of animals spent all the time during the experiment in an individually ventilated plastic cage. The serum CORT concentrations were determined in all 4 groups of the rats. The blood samples drawn from the tail vein were collected every day after termination of the 6-h exposure. On the fifth day, blood samples were collected $15 \mathrm{~min}, 30 \mathrm{~min}, 45 \mathrm{~min}, 1 \mathrm{~h}$, and $3 \mathrm{~h}$ after termination of the 6-h exposure. Results: On the fifth day of the study, no statistically significant changes in body weights between all groups of animals were found. After 5 days of the observation, increased food intake in the control groups was noted. Significantly higher CORT concentrations in the rats exposed to $1-\mathrm{MN}$ at $200 \mathrm{mg} / \mathrm{m}^{3}$ and in the animals from the control restrainer were found, comparing to the animals exposed to 1-MN at $50 \mathrm{mg} / \mathrm{m}^{3}$ and the animals from the control cage. Conclusions: The application of 6-h restraining induced high concentrations of the stress hormone, CORT, in the blood of rats. The short-term exposure of rats to 1-MN non-linearly reduced the restraint stress measured with CORT concentration. Int J Occup Med Environ Health. 2020;33(5):691-9
\end{abstract}

Key words:

rat, corticosterone, HPA, inhalation exposure, 1-methylnaphthalene, restraining stress

\section{INTRODUCTION}

Each stimulus, situation or condition resulting in the activation of the hypothalamic-pituitary-adrenal (HPA) axis is considered a stressor. Adrenal cortex hormones, including in particular glucocorticoids, constitute an essential link in the process of adaptation to a strong stress. Glucocorticoids are 21-carbon steroids showing various biological effects, the major being the gluconeogenesis-stimulating effect. Corticosterone (CORT) is the strongest glucocorticoid in rats [1].
Stressful experiences in humans can result in a spectrum of long-term changes in behavioral, autonomic and hormonal responsivity [2]. Exposure to a chemical reagent, or a physical, immunological, bacterial or psychological stimulus, may activate or suppress the HPA axis in animals [3-12]. The activation of the HPA axis in animals has been found to induce higher levels of serum CORT concentrations. Assay for blood CORT levels in animals is a good biomarker of stress that can be induced by strong and even weak stressors. Increases in plasma cortisol in

Funding: This research was supported under the statutory activities of the Nofer Institute of Occupational Medicine (IMP grant 1.17 "Toxicokinetics of 1-methylnaphthalene in rats under conditions of inhalation exposure and in vitro assessment of the mutagenic activity of urinary extracts from 1-methylnaphthalene exposed animals," project manager: Radosław Świercz, Ph.D.).

Received: May 8, 2019. Accepted: June 17, 2020.

Corresponding author: Radosław Świercz, Nofer Institute of Occupational Medicine, Department of Toxicology and Carcinogenesis, św. Teresy 8, 91-348 Łódź, Poland (e-mail: Radoslaw.Swiercz@imp.lodz.pl). 
humans, or CORT in rodents, result from exposures to stressors [13].

Alcohol dependence is linked to the dysregulation of the HPA axis. Increased plasma CORT concentrations have been observed after chronic intermittent ethanol vapor inhalation and abstinence in animals after the end of the exposure to ethanol vapors [14,15].

A consistent symptom of intoxication by organophosphate compounds is a strong activation of the HPA axis, which is evidenced by a manifold and relatively long-lasting increase in serum CORT concentrations [16-18].

1-Methylnaphthalene (1-MN), a clear liquid, is widely utilized mainly as a solvent for pesticides and fungicides, as an intermediate of organic synthesis (e.g., in the synthesis of various polycyclic aromatic hydrocarbons, including naphtho[a]carbazoles and naphthopyrones), as a dye carrier, in resins, and others. The American Conference of Governmental Industrial Hygienists has suggested an 8-h time-weighted average threshold limit value (TLV) of $0.5 \mathrm{ppm}\left(3 \mathrm{mg} / \mathrm{m}^{3}\right)$ since 2007 [19]. The substance can be absorbed into the body by inhalation of its aerosol or vapor, by ingestion and skin [20].

It has been shown that 1-MN accumulates in the body and induces toxicity, especially in the lungs [21,22]. Murata et al. [23] reported no lung toxicity in mice in a 13-week repeated dose toxicity study. However, Kim et al. [24] reported that in the rats exposed by inhalation to $1-\mathrm{MN}$, some toxic effects were observed in the upper respiratory system and the no-observed-adverse-effect level was suggested to be $4 \mathrm{ppm}$ on the basis of histopathological findings. In addition, 1-MN showed lung carcinogenicity in the mice fed a diet containing $0.075 \%$ or $0.15 \% 1-\mathrm{MN}$ [23]. Although $1-\mathrm{MN}$ was positive in some mutagenicity endpoints (the sister chromatid exchange test), it was proved to be negative in the Ames test.

Korsak et al. [25] reported some neurotoxic and sensory respiratory irritation effects in the rats acutely exposed to $1-\mathrm{MN}$ by inhalation, and the results showed that sensitivity to pain decreased in the animals after exposure to $44 \mathrm{ppm}$ $\left(256 \mathrm{mg} / \mathrm{m}^{3}\right)$ or $70 \mathrm{ppm}\left(408 \mathrm{mg} / \mathrm{m}^{3}\right)$ for $4 \mathrm{~h}$, but not after exposure to $26 \mathrm{ppm}\left(151 \mathrm{mg} / \mathrm{m}^{3}\right)$.

Considering wide industrial applications of $1-\mathrm{MN}$ and some toxicological effects in animals after inhalation exposure, the current study was undertaken to provide more insight in potential neurological disturbances after exposure to $1-\mathrm{MN}$.

The specific aims of the work were:

- to assess the trend of the stressogenic experience caused by repeated exposure to $1-\mathrm{MN}$ vapors at the nominal concentrations of $0 \mathrm{mg} / \mathrm{m}^{3}$ (the control restrainer), $50 \mathrm{mg} / \mathrm{m}^{3}$ or $200 \mathrm{mg} / \mathrm{m}^{3}$ in the nose-only inhalation system by analyzing the serum CORT levels in rats;

- to investigate 1 group of animals which spent all the time during the experiment in an individually ventilated plastic cage (the control cage) by analyzing the serum CORT levels in rats.

\section{MATERIAL AND METHODS}

\section{Chemicals}

1-Methylnaphthalene (1-MN, CAS No.: 90-12-0) was supplied by Riedel-de Haën (Seelze, Germany). Its chemical purity was $98 \%$.

\section{Animal groups and the collection of biological material} Overall, 12 male Wistar rats IMP WIST were used in the experiment. The rats were 2-3 months old and weighed 222-262 $\mathrm{g}$ at the experiment onset. After a 1-week acclimation, the animals were divided into 4 treatment groups ( 3 animals in each group). Before the experiment and during its course, they were housed in individual ventilated plastic cages (Tecniplast S.p.A., Varese, Italy) at $20-24^{\circ} \mathrm{C}$ and humidity at $45-65 \%$, with a light/dark cycle of $12 / 12 \mathrm{~h}$ (light on at 6:00 a.m.). The animals were given standard rat food pellets (Murigran: AGROPOL, Motycz, Poland) and water ad libitum, except for the exposure to 1-MN vapors in the dynamic inhalation chambers. Body weight was measured once a day 
Table 1. Design of the experiment, experimental groups, treatment, concentrations of 1-methylnaphtalene (1-MN) vapors in inhalation chambers, in the study conducted at the Nofer Institute of Occupational Medicine, Department of Toxicology and Carcinogenesis, Łódź, Poland, in 2014

\begin{tabular}{llc}
\hline Group & \multicolumn{1}{c}{ Treatment } & $\begin{array}{c}\text { 1-MN concentration* } \\
{\left[\mathrm{mg} / \mathrm{m}^{3}\right]} \\
(\mathrm{M} \pm \mathrm{SD})\end{array}$ \\
\hline Group 1 & $\begin{array}{l}\text { Control animals were not kept in the chamber }(\mathrm{N}=3)^{* *} \\
\text { Control animals were kept in the chamber } \\
\text { Group 2 }\end{array}$ & 0 (control cage) \\
Group 3 & $\begin{array}{l}\text { 1-MN target concentration of } 50 \mathrm{mg} / \mathrm{m}^{3} \\
5 \text { days, } 6 \text { h/day }(\mathrm{N}=3)\end{array}$ & 0 (control restrainer) \\
Group 4 & $\begin{array}{l}\text { 1-MN target concentration of } 200 \mathrm{mg} / \mathrm{m}^{3} \\
5 \text { days, } 6 \text { h/day }(\mathrm{N}=3)\end{array}$ & $53.7 \pm 4.1$ \\
\hline
\end{tabular}

* Concentrations of 1-MN vapors in inhalation chambers.

** Number of animals per treatment.

(in the morning). During the 5-day observation, the animals were monitored for the intake of water and feed.

Overall, 3 groups of rats ( $\mathrm{N}=3$ /group) were exposed to 1 -MN vapors at the nominal concentration of $0 \mathrm{mg} / \mathrm{m}^{3}$ (the control restrainer), $50 \mathrm{mg} / \mathrm{m}^{3}$, or $200 \mathrm{mg} / \mathrm{m}^{3}$ in the noseonly inhalation system for 5 days ( $6 \mathrm{~h} /$ day, exposure started at 8:00 a.m.). One group of animals $(\mathrm{N}=3)$ was kept for the whole experiment in an individually ventilated plastic cage (the control cage).

The serum CORT concentrations were determined in all 4 groups of rats (Table 1). Venous blood samples $(200 \mu \mathrm{l})$ were drawn from the tail vein (the "nick" method) every day after termination of the exposure to 1-MN vapors. On the fifth day, blood samples were collected $15 \mathrm{~min}, 30 \mathrm{~min}, 45 \mathrm{~min}, 1 \mathrm{~h}$, and $3 \mathrm{~h}$ after termination of the exposure to 1-MN. The time points for blood samples collection were identical for the control groups.

The Local Ethics Committee for Experiments on Animals approved the study protocol (Opinion No. 22/ $/ \mathrm{EB}$ 544/2011).

\section{Serum CORT assays}

The serum CORT concentrations were determined in $200 \mu \mathrm{l}$ samples of blood drawn from the tail vein into Eppendorf vials. The samples were left at room temperature until they clotted, and then they were centrifuged at $4000 \mathrm{rpm}$ (10 min). The collected samples were stored in Eppendorf vessels at $-20^{\circ} \mathrm{C}$ until the analysis.

The serum CORT concentration was estimated by means of high pressure liquid chromatography (HPLC) using betamethasone as an internal standard [26]. Betamethasone was added to $40 \mu \mathrm{l}$ of the serum, mixed on a vortex, and then a $2 \mathrm{ml}$ diethyl ether/dichloromethane solution $(60: 40$, v/v) was added. The samples were shaken for $3 \mathrm{~min}$ and centrifuged for $5 \mathrm{~min}$ (4000 rpm). The extract was transferred to other vials and evaporated to dryness under the nitrogen atmosphere. The dry residue was dissolved in $100 \mu$ of the mobile phase; $20 \mu \mathrm{l}$ of the sample was collected for chromatographic analysis. For the analytical method, corticosterone (Sigma-Aldrich, St. Louis, USA) as a standard, $\beta$-methasone (Sigma-Aldrich, St. Louis, USA) as an internal standard, methanol (Avantor Performance Materials Poland S.A., Gliwice, Poland), dichloromethane (Avantor Performance Materials V.B., Dewenter, Netherlands) and diethyl ether (Avantor Performance Materials, Inc. Center Valley, USA) were used in the study.

An integrated analytical system of HPLC, Waters 2695 Integrity System equipped with a UV-VIS detector (Waters 996), with the range of 190-800 nm, was used to 
determine the study compounds. Chromatographic separations were performed on a ZORBAX SB-C18 column $(2,1 \times 150 \mathrm{~mm}, 5$ um, Agilent Technologies, Inc., Santa Clara, USA). Determination conditions were as follows: mobile phase - methanol:deionized water $(55: 45, \mathrm{v} / \mathrm{v})$, mobile phase flow $-0.4 \mathrm{ml} / \mathrm{min}$, injection volume $-20 \mu \mathrm{l}$, length of the analytical wave: $250 \mathrm{~nm}$, total time - $25 \mathrm{~min}$. The limit of detection for CORT was $5 \mathrm{ng} / \mathrm{ml}$ of serum analysis.

\section{Inhalation and exposure monitoring}

Inhalation exposure in the rats was performed using the TSE Systems Head-Nose-Only Exposure Units (TSE Systems, Bad Homburg, Germany). The animals were exposed to 1 -MN vapors in the dynamic airflow of $\geq 15$ air changes/h. During the exposure, the rats were placed in glass restrainer tubes. Temperature, humidity and airflow in the head-nose-only exposure unit were monitored during each exposure period (TSE Daco Software, Bad Homburg, Germany). Vapors were generated by a metering unit equipped with a syringe pump and an ultrasonic nebulizer. The desired concentrations of vapors were obtained by diluting them with the air.

Vapor samples ( $0.5 \mathrm{l})$ were absorbed on a $2 \mathrm{ml}$ liquid sorbent (ethyl alcohol from Polmos, Poland; concentration: 95\%). Concentrations of solvent vapors in the exposure chamber were measured every 30 min by gas chromatography (HewlettPackard 6890) with a flame ionization detector (FID) using capillary column (HP-5; $50 \mathrm{~m} \times 0.32 \mathrm{~mm} \times 1.05 \mathrm{~mm}$ film thickness). The operating conditions were as follows: carrier gas - helium, constant flow mode, column flow $-1.4 \mathrm{ml} / \mathrm{min}$, make-up gas (helium) - $30 \mathrm{ml} / \mathrm{min}$, air - $300 \mathrm{ml} / \mathrm{min}$, oven $110^{\circ} \mathrm{C}$, inlet split $-230^{\circ} \mathrm{C}$, detector $-260^{\circ} \mathrm{C}$.

The target exposure to 1-MN vapor concentrations were $50 \mathrm{mg} / \mathrm{m}^{3}$ and $200 \mathrm{mg} / \mathrm{m}^{3}$. Measured chamber concentrations during the single and repeated inhalation study $\mathrm{M} \pm \mathrm{SD}$ were $53.7 \pm 4.1 \mathrm{mg} / \mathrm{m}^{3}$ and $194.5 \pm 10.8 \mathrm{mg} / \mathrm{m}^{3}$, respectively. The relative temperature in the chamber was maintained at $20-23^{\circ} \mathrm{C}$ and humidity at $42-43 \%$.

\section{Statistical analysis}

Statistical analyses were performed by means of the 1-way analysis of variance test (SigmaStat 4.0 for Windows); $\mathrm{p}<0.05$ was considered significant.

\section{RESULTS}

Table 1 shows experimental groups of the rats, from which biological material was collected for further analysis, and the actual 1-MN vapor concentration in toxicological chambers. Body weights of the rats at the start (the first day) and at the end of the experiment (the fifth day) are shown in Figure 1. On the first day, an occasional statistically significant difference between the control cage group and the group then targeted to 1-MN $200 \mathrm{mg} / \mathrm{m}^{3}$ was observed. On the fifth day, no statistically significant change was found in body weights between all groups of animals (Figure 1). After 5 days of observation, a decreased food intake in the exposed groups was noted. The animals exposed to $1-\mathrm{MN}$ at $50 \mathrm{mg} / \mathrm{m}^{3}$ showed a slight increase in water intake (Figure 2).

Figure 3 shows the dynamics of changes of the serum CORT concentrations in the rats observed for 5 days. At the end of the study, increased CORT concentrations in the rats exposed to $1-\mathrm{MN}$ at $200 \mathrm{mg} / \mathrm{m}^{3}$ and the animals from the control restrainer group were observed, comparing to the control cage group and the group exposed to $1-\mathrm{MN}$ at $50 \mathrm{mg} / \mathrm{m}^{3}$. No significant differences were noted in the CORT levels between the group exposed to 1-MN at $50 \mathrm{mg} / \mathrm{m}^{3}$ and the animals kept in the control cage for the first, second and third day of the study. A significant increase in the serum CORT concentration was observed between the group exposed to $1-\mathrm{MN}$ at $50 \mathrm{mg} / \mathrm{m}^{3}$ and the animals from the control cage, on the fourth and fifth day of the study.

During the first 30 min after termination of the 6-h exposure on the fifth day, the serum CORT concentration rapidly increased in the rats exposed to 1-MN (2 groups) and the animals from the control cage. During the first $45 \mathrm{~min}$ 


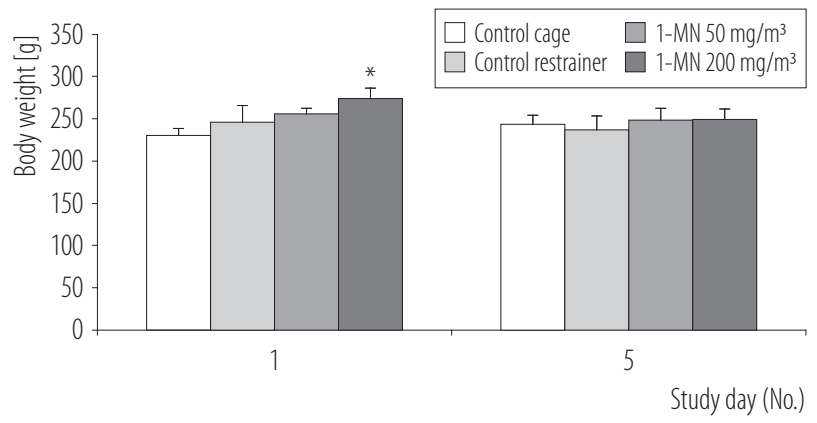

Data are expressed as $\mathrm{M} \pm \mathrm{SD}$.

$* \mathrm{p}<0.05$ compared to the control cage.

Figure 1. Body weights of the rats in different groups at the start and at the end of the study conducted at the Nofer Institute of Occupational Medicine, Department of Toxicology and Carcinogenesis, Łódź, Poland, in 2014

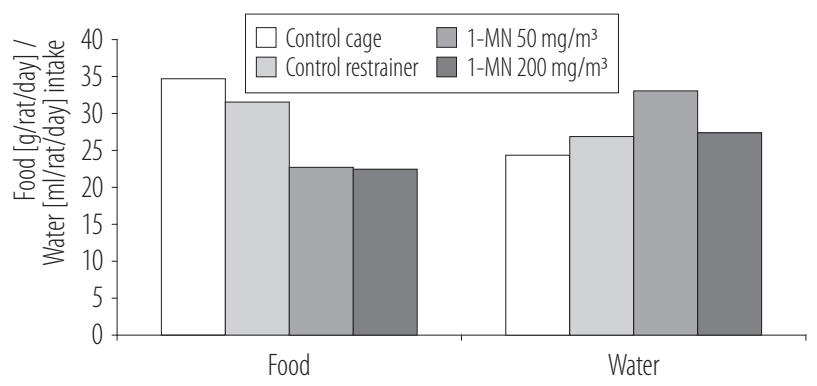

The animals from each group were kept in 1 cage; therefore, individual data are unavailable.

Figure 2. Mean food and water intake parameters in the study groups during 5 days of the experiment, in the study conducted at the Nofer Institute of Occupational Medicine, Department of Toxicology and Carcinogenesis, Łódź, Poland, in 2014 after the exposure termination, the CORT concentration was slowly diminishing in the rats from the control restrainer. After $3 \mathrm{~h}$, the CORT concentrations were at similar low levels in all groups of animals (Figure 4). Figure 5 presents the area under curve (AUC) values calculated for the CORT data for all experimental groups after termination of the study. The AUC evidently increased after exposure to $1-\mathrm{MN}$ at $50 \mathrm{mg} / \mathrm{m}^{3}$ and $200 \mathrm{mg} / \mathrm{m}^{3}$ as compared to 2 control groups. The AUC decreased after sham exposure (the control restrainer) as compared to the control cage.

\section{DISCUSSION}

A quantitative analysis of the serum CORT concentrations in rats is a good marker illustrating a dose-related stress in the experimental animals after inhalation exposure to 1-MN. In this study, the application of 6-h restraint stress increased the CORT levels in rats while inhalation exposure to $1-\mathrm{MN}$ at $50 \mathrm{mg} / \mathrm{m}^{3}$ significantly reduced the stress. These results suggest that 1-MN interacts with the HPA axis similarly to many volatile compounds [3,11,27-31]. The non-linear effect on the stress level, as observed in this study, was also reported for other organic solvents like 1,2,4-trimethylbenzene (pseudocumene [PS]) or 1,2,3-trimethylbenzene (hemimellitene [HM]) [32-34]. In the study by

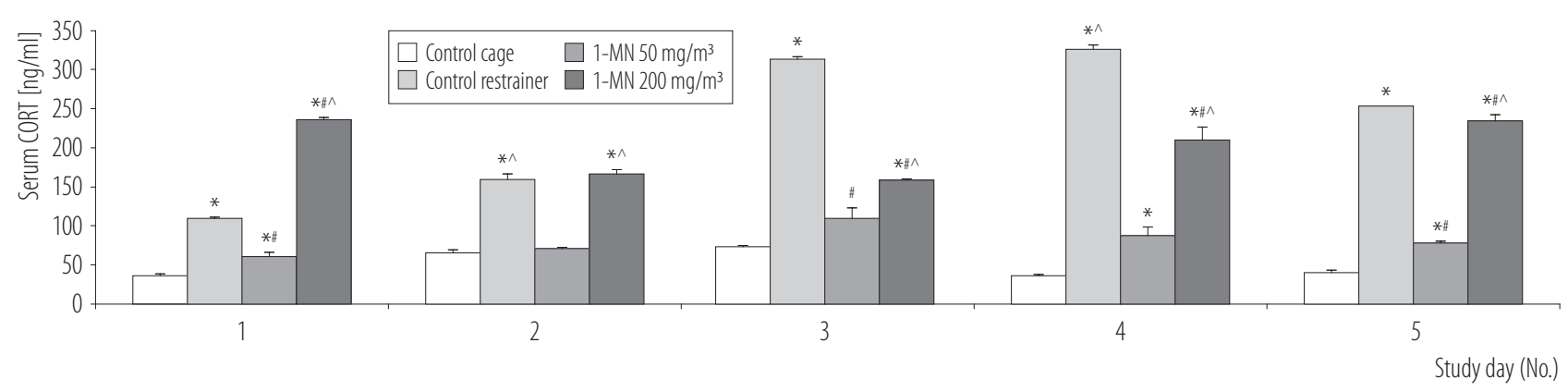

Data are expressed as $\mathrm{M} \pm \mathrm{SD}$.

${ }^{*} \mathrm{p}<0.05$ compared to the control cage; ${ }^{\#} \mathrm{p}<0.05$ compared to the control restrainer; ${ }^{\wedge} \mathrm{p}<0.05$ compared to $1-\mathrm{MN}$ at $50 \mathrm{mg} / \mathrm{m}^{3}$.

Figure 3. The serum corticosterone (CORT) concentration in the rats within 5 days of the experiment, in the study conducted at the Nofer Institute of Occupational Medicine, Department of Toxicology and Carcinogenesis in Łódź, Poland, in 2014 


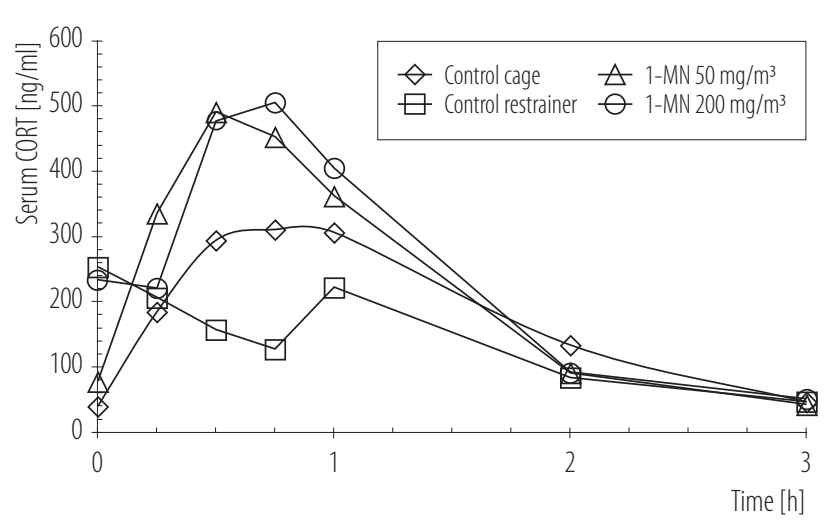

Data are expressed as mean values ( $\mathrm{N}=3$ per group).

Figure 4. Serum corticosterone (CORT) concentrations in the rats during the first $3 \mathrm{~h}$ after termination of the 6-h exposure on the fifth day, in the study conducted at the Nofer Institute of Occupational Medicine, Department of Toxicology and Carcinogenesis in Łódź, Poland, in 2014

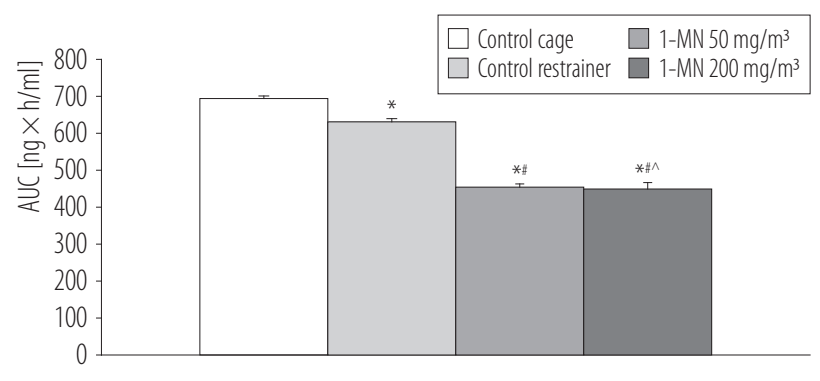

Data are expressed as $\mathrm{M} \pm \mathrm{SD}$ in rats ( $\mathrm{N}=3$ per group). ${ }^{*} \mathrm{p}<0.05$ compared to the control cage; $\# \mathrm{p}<0.05$ compared to the control restrainer; $\wedge$ p $<0.05$ compared to the group exposed to $1-\mathrm{MN}$ at $50 \mathrm{mg} / \mathrm{m}^{3}$.

Figure 5. Area under curve (AUC) values for the corticosterone data for all experimental groups during the first $3 \mathrm{~h}$ after termination of the 6-h exposure on the fifth day, in the study conducted at the Nofer Institute of Occupational Medicine, Department of Toxicology and Carcinogenesis in Łódź, Poland, in 2014

Wiaderna et al. [34], the effects of a repeated 4-week (6 h/day, 5 days/week) inhalation exposure to PS or HM at concentrations of $0 \mathrm{ppm}, 25 \mathrm{ppm}, 100 \mathrm{ppm}$ or $250 \mathrm{ppm}$ $\left(0 \mathrm{mg} / \mathrm{m}^{3}, 123 \mathrm{mg} / \mathrm{m}^{3}, 492 \mathrm{mg} / \mathrm{m}^{3}\right.$ or $\left.1230 \mathrm{mg} / \mathrm{m}^{3}\right)$, on some behavioral endpoints (e.g., an impaired learning of passive and active avoidance responses, and a longer persistence of an effect of footshock (the increase in latency of the paw-lick response to heat) were more pronounced after the exposure to lower PS or HM concentrations. The results of this study are also corroborated by other reports where a short time of restraint stress increased the serum CORT levels in animals [12,30]. The data in this study indicate similar CORT concentrations in the rats lasting for $\geq 2 \mathrm{~h}$ after termination of the exposure to $1-\mathrm{MN}$. In comparison to the control restrainer group, the changes in CORT concentrations were different and ran with various dynamics. In the animals that were exposed only to restraint stress, the serum CORT levels quickly decreased after cessation of the stress. This result shows that the collection of venous blood from the tail has no significant influence on stress. Probably this restraint stress was so high that the act of drawing blood samples from the tail did not stimulate the HPA axis, in contrast to the animals that spent the whole experiment in an individually ventilated plastic cage (the control cage).

Exposure to $1-\mathrm{MN}$ at $50 \mathrm{mg} / \mathrm{m}^{3}$ suppressed the stress induced by restraining; however, after $3 \mathrm{~h}$ of the observation, the AUC values calculated for CORT increased as compared to the control groups. Similarly, the high AUC observed in the animals exposed to $1-\mathrm{MN}$ at concentrations of $50 \mathrm{mg} / \mathrm{m}^{3}$ or $200 \mathrm{mg} / \mathrm{m}^{3}$ can be related to similar levels of 1-MN measured in the brains of these animals [35]. The difference in the value of AUC between the control groups may result from the high stress induced by restraining. Interestingly, the study by Jameel et al. [36] provided evidence that the rise in the serum cortisol level in rats was significantly higher after the restraint test than when exposing them to the forced swim test. In this study, control restraining could be so effective as to influence the stress reaction stimulated by the act of drawing a blood sample alone. The animals that spent the whole experiment in an individual cage and were sampled for blood showed the highest CORT concentration after $1 \mathrm{~h}$. These results demonstrate the normal response of the HPA axis to stress. 


\section{CONCLUSIONS}

In conclusion, the results of this study indicate that 1-MN attenuated the HPA axis function by reducing the CORT stress response. The application of 6-h restraint stress induced high concentrations of the stress hormone, CORT, in the blood of rats. The short-term exposure of the animals to $1-\mathrm{MN}$ non-linearly reduced the restraint stress measured by CORT concentration.

\section{ACKNOWLEDGMENTS}

The authors are grateful to Zofia Grzelińska for biochemical analysis and to Krzysztof Mader for his excellent technical assistance.

\section{REFERENCES}

1. Engelmann M, Landgraf R, Wotjtak CT. The hypothalamicneurohypophysial system regulates the hypothalamic-pituitary-adrenal axis under stress: An old concept revisited. Front Neuroendocrinol. 2004;25(3-4):132-49, https://doi.org/ 10.1016/j.yfrne.2004.09.001.

2. Stam R, Bruijnzeel AW, Wiegant VM. Long-lasting stress sensitisation. Eur J Pharmacol. 2000;405(1-3):217-24.

3. Ayuob NN. Evaluation of the antidepressant-like effect of musk in an animal model of depression: how it works. Anat Sci Int. 2017;92(4):539-53, https://doi.org/10.1007/s12565-0160357-7.

4. Bekhbat M, Merrill L, Kelly SD, Lee VK, Neigh GN. Brief anesthesia by isoflurane alters plasma corticosterone levels distinctly in male and female rats: Implications for tissue collection methods. Behav Brain Res. 2016;305:122-5, https:// doi.org/10.1016/j.bbr.2016.03.003.

5. Gater ST, Peters KN, Kocsis AG, Dhariwala MO, Anderson DM, Anderson PE. Host stress and immune responses during aerosol challenge of Brown Norway rats with Yersinia pestis. Front Cell Infect Microbiol. 2012;2:147, https://doi. org/10.3389/fcimb.2012.00147.

6. Goble KH, Bain ZA, Padow VA, Lui P, Klein ZA, Romeo RD. Pubertal-related changes in hypothalamic-pituitary-adrenal axis reactivity and cytokine secretion in response to an immunological stressor. J Neuroendocrinol. 2011;23(2):12935, https://doi.org/10.1111/j.1365-2826.2010.02085.x.

7. Gotohda T, Tokunaga I, Kubo S. Toluene inhalation-induced adrenocortical hypertrophy and endocrinological changes in rat. Life Sci. 2005;76(17):1929-37, https://doi.org/10.1016/ j.lfs.2004.08.035.

8. Lino-dos-Santos-Franco A, Amemiya RM, Ligeiro de Oliveira AP, Breithaupt-Faloppa AC, Damazo AS, OliveiraFilho RM, et al. Differential effects of female sex hormones on cellular recruitment and tracheal reactivity after formaldehyde exposure. Toxicol Lett. 2011;205(3):327-35, https:// doi.org/10.1016/j.toxlet.2011.06.023.

9. Okuyama K, Dobashi K, Miyasaka T, Yamazaki N, Kikuchi T, Sora I, et al. The involvement of glucocorticoids in psychological stress-induced exacerbations of experimental allergic asthma. Int Arch Allergy Immunol. 2014;163(4):297-306, https://doi.org/10.1159/000360577.

10. Peña-Philippides JC, Razani-Boroujerdi S, Singh SP, Langley RJ, Mishra NC, Henderson RF, et al. Long- and short-term changes in the neuroimmune-endocrine parameters following inhalation exposures of F344 rats to low-dose sarin. Toxicol Sci. 2007;97(1):181-8, https://doi.org/10.1093/toxsci/kfm017.

11. Saiyudthong S, Mekseepralard C. Effect of inhaling bergamot oil on depression-related behaviors in chronic stressed rats. J Med Assoc Thai. 2015;98(Suppl 9):S152-9.

12. Umeoka EH, Garcia SB, Antunes-Rodrigues J, Elias LL, Garcia-Cairasco N. Functional characterization of the hypothalamic-pituitary-adrenal axis of the Wistar Audiogenic Rat (WAR) strain. Brain Res. 2011;1381:141-7, https://doi.org/ 10.1016/j.brainres.2011.01.042.

13. Kelly KA, Michalovicz LT, Miller JV, Castranova V, Miller DB, O'Callaghan JP. Prior exposure to corticosterone markedly enhances and prolongs the neuroinflammatory response to systemic challenge with LPS. PLoS One. 2018;13(1):e0190546, https://doi.org/10.1371/journal.pone.0190546.

14. Somkuwar SS, Vendruscolo LF, Fannon MJ, Schmeichel BE, Nguyen TB, Guevara J, et al. Abstinence from prolonged 
ethanol exposure affects plasma corticosterone, glucocorticoid receptor signaling and stress-related behaviors. Psychoneuroendocrinology. 2017;84:17-31, https://doi.org/10. 1016/j.psyneuen.2017.06.006.

15. Wilhelm CJ, Hashimoto JG, Roberts ML, Bloom SH, Beard DK, Wiren KM. Females uniquely vulnerable to alcohol-induced neurotoxicity show altered glucocorticoid signaling. Brain Res. 2015;1601:102-16, https://doi.org/10.1016/ j.brainres.2015.01.002.

16. Gralewicz S, Lutz P, Kur B. Pretreatment with footshock alters some effects of subsequent organophosphate exposure. Neurotoxicology. 2005;26(2):159-71, https://doi.org/ 10.1016/j.neuro.2004.12.003.

17. Osicka-Koprowska A, Lipska M, Wysocka-Paruszewska B. Effects of chlorfenvinphos on plasma corticosterone and aldosterone levels in rats. Arch Toxicol. 1984;55(1):68-9.

18. Świercz R, Lutz P, Gralewicz S, Grzelińska Z, Piasecka-Zelga J, Wąsowicz W. Partial protection from organophosphateinduced cholinesterase inhibition by metyrapone treatment. Int J Occup Med Environ Health. 2013;26(4):636-46, https:// doi.org/10.2478/s13382-013-0131-1.

19. American Conference of Governmental Hygienists Inc. 1-Methylnaphthalne and 2-methylnaphthalene. Documentationof the threshold limit values and biological exposure indices, 7th edition. Cincinnati, OH: ACGIH; 2007.

20. Kim D, Andersen ME, Nylander-French LA. Dermal Absorption and Penetration of Jet Fuel Components in Humans. Toxicol Lett. 2006;165(1):11-21, https//doi.org/10.1016/j.toxlet. 2006.01.009.

21. McCain BB, Hodgins HO, Gronlund WD, Hawkes JW, Brown DW, Myers MS, et al. Bioavailability of crude oil from experimentally oiled sediments to English sole (Parophrys vetulus), and pathological consequences. J Fish Res Board Can. 1978;35(5):657-64, https//doi.org/10.1139/f78-115.

22. Dinsdale D, Verschoyle RD. Pulmonary toxicity of naphthalene derivatives in the rat. Arch Toxicol. 1986;Suppl(11):288-91.

23. Murata Y, Denda A, Maruyama H, Konishi Y. Chronic toxicity and carcinogenicity studies of 1-methylnaphthalene in B6C3F1 mice. Fundam Appl Toxicol. 1993;21(1):44-51, https//doi.org/10.1006/faat.1993.1070.

24. Kim YS, Lee MJ, Seo DS, Kim TH, Kim MH, Lim CH. Thirteen-week inhalation toxicity study of 1-methylnaphthalene in F344 rats. Toxicol Res. 2019;36(1):13-20, https//doi. org/10.1007/s43188-019-00009-1.

25. Korsak Z, Majcherek W, Rydzynski K. Toxic effects of acute inhalation exposure to 1-methylnaphthalene and 2-methylnaphthalene in experimental animals. Int J Occup Med Environ Health. 1998;11(4):335-42.

26. Ling S, Jamali F. Effect of cannulation surgery and restraint stress on the plasma corticosterone concentration in the rat: application of an improved corticosterone HPLC assay. J Pharm Pharmaceuti Sci. 2003;6(2):246-51.

27. Fujita S, Ueki S, Miyoshi M, Watanabe T. "Green odor" inhalation by stressed rat dams reduces behavioral and neuroendocrine signs of prenatal stress in the offspring. Horm Behav. 2010;58(2):264-72, https://doi.org/10.1016/j. yhbeh.2010.03.007.

28. Fukada M, Kano E, Miyoshi M, Komaki R, Watanabe T. Effect of "rose essential oil" inhalation on stress-induced skin-barrier disruption in rats and humans. Chem Senses. 2012;37(4):347-56, https://doi.org/10.1093/chemse/bjr108.

29. Saiyudthong S, Marsden CA. Acute effects of bergamot oil on anxiety-related behaviour and corticosterone level in rats. Phytother Res. 2011;25(6):858-62, https://doi.org/10.1002/ptr.3325.

30. Takemoto H, Omameuda Y, Ito M, Fukuda T, Kaneko S, Akaike A, et al. Inhalation administration of valerena4,7(11)-diene from Nardostachys chinensis roots ameliorates restraint stress-induced changes in murine behavior and stress-related factors. Biol Pharm Bull. 2014;37(6):1050-5.

31. Villareal MO, Ikeya A, Sasaki K, Arfa AB, Neffati M, Isoda H. Anti-stress and neuronal cell differentiation induction effects of Rosmarinus officinalis L. essential oil. BMC Complement Altern Med. 2017;17(1):549, https://doi.org/10.1186/ s12906-017-2060-1.

32. Gralewicz S, Wiaderna D, Tomas T, Rydzyński K. Behavioral changes following 4-week inhalation exposure to pseudoc- 
umene (1,2,4-trimethylbenzene) in the rat. Neurotoxicol Terato. 1997;19(4):327-33, https//doi.org/10.1016/s0892-0362(97) 00001-9.

33. Gralewicz S, Wiaderna D, Tomas T. Retardation of the agerelated increase in spontaneous cortical spike-wave discharges (SWD) in rats after a 28-day inhalation (SWD) in rats after a 28-day inhalation exposure to an industrial solvent, pseudocumene (1,2,4-trimethylbenzene). Int J Occup Med Environ Health. 1997;10(2):213-22.

34. Wiaderna D, Gralewicz S, Tomas T. Behavioural changes following a four-week inhalation exposure to hemimellitene (1,2,3-trimethylbenzene) in rats. Int J Occup Med Environ Health. 1998;11(4):319-34.

35. Świercz R, Wąsowicz W. The distribution and excretion of 1-methylnaphthalene in rats exposed to 1-methylnaphtalene by inhalation. Int J Occup Med Environ Health. 2018;31(6):76370, https://doi.org/10.13075/ijomeh.1896.01224.

36. Jameel MK, Joshi AR, Dawane J, Padwal M, Joshi A, Pandit VA, et al. Effect of various physical stress models on serum cortisol level in wistar rats. J Clin Diagn Res. 2014;8(3):1813, https//doi.org/10.7860/JCDR/2014/7210.4116.

This work is available in Open Access model and licensed under a Creative Commons Attribution-NonCommercial 3.0 Poland License - http://creativecommons.org/ licenses/by-nc/3.0/pl/deed.en. 